\title{
The Influence of Principal Leadership and Management on Teacher Performance
}

\author{
Jazaudin $^{1 *}$, Happy Fitria ${ }^{2}$, Achmad Wahidy ${ }^{2}$

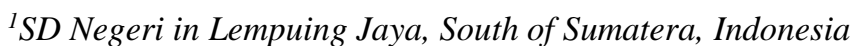 \\ ${ }^{2}$ Universitas PGRI Palembang, Indonesia \\ *Corresponding author. Email: jazaudin@gmail.com
}

\begin{abstract}
The purpose of this research is to discover and analyze: (1) the impact of leadership on teacher performance; (2) the impact of the headmaster's management on teacher performance; and (3) the partial or simultaneous impact of the headmaster's leadership and management on teacher performance. This is a quantitative study using an ex post facto research approach. This study was carried out at SD Negeri Kecamatan Lempuing Jaya Ogan Komering Ilir Regency with a population of 259 teachers for the withdrawal of research samples using proportional random sampling, and 72 respondents were obtained. Documentation and questionnaires that have been tested for validity and reliability are used in this study's data collection procedures. Run the normality test, autocorrelation test, heterosesedastisity test, and multicollinierity test are used to meet the criteria of the analysis. Techniques for data analysis based on the test and the $\mathrm{F}$ test. The findings of this study indicate that the principal's leadership and management have an impact on the performance of public elementary school teachers in Lempuing Jaya Subdistrict Ogan Komering Ilir Regency, both individually and concurrently.
\end{abstract}

Keywords: Leadership, Principal Management, Teacher Performance

\section{INTRODUCTION}

The development of education in Indonesia with the enactment of Permendiknas RI. Number 16 Year 2007 [1] concerning provisions on teachers in positions that have not met the academic qualifications of diploma four (D-IV) or bachelor (S1) will be regulated by a separate Ministerial Regulation. The implementation of local government brings logical consequences to the paradigm change in education management from centralistic to decentralises. This change, on the one hand, is beneficial because education in schools can be implemented more freely and independently in accordance with the ability of each school, but on the other hand it will be an obstacle to its implementation if the readiness of the school is not in line with the demands of the Permendiknas policy. One of the government's efforts to support the implementation of permendiknas is to improve teacher education qualifications through equalization programs. Elementary school teachers must have a minimum background (S.1). These efforts are still complemented by various trainings and management and certification of teachers whose implementation will begin this year. The effort indicates that teachers still need to improve their performance. The work process or the results of work may reveal information about a teacher's performance. A job always has work procedures, and work processes always result in an increase in work results that are in accordance with the demands of the job. If a task is completed in accordance with the process, it will result in the desired work. The performance benchmark is the work demands that characterize the work to be completed. The extent to which a person is able to do the job in comparison to the results obtained is referred to as a person's performance on the job.

According to Damin, et al [2] the consequence of an employee's performance is the quality and quantity of work completed in carrying out his duties in accordance with the tasks assigned to him. Workers' high achievement is closely linked to the awarding system used by the institutions/organizations where they work. According to Tjutju, et al [3] performance is a real achievement displayed by someone concerned in carrying out their duties and roles in the organization in a more measured manner. Risnawatiririn [4] cites some expert opinions on the following performance, according to Gomes, performance is a record of production results on particular work functions or tasks over a specific time period. According to Fattah, performance is an expression of ability based on experience, attitude, and skills, as well as motivation to produce something. According to Samsudin, performance is the level of task implementation that a person, unit, or division can accomplish by using 
existing capacities and boundaries that have been set to achieve the organization's / company's goals.

Based on performance standards established over a specific time period in terms of achieving organizational goals. A teacher who has high performance should have a positive attitude towards the work he/she is facing, such attitudes as discipline, like to work earnestly, maintain the quality of his work, be responsible, be highly dedicated and so on. As a result of the importance of teacher performance in its role in improving educational success, it is absolutely necessary for teachers to perform well. What factors influence the improvement of teacher performance must be identified immediately so that the issue of improving educational quality, particularly in SD Negeri Lempuing Jaya District Ogan Komering Ilir, can be resolved as soon as possible. Teachers are the primary key to improving educational quality because the most important requirement for the realization of a quality education is that the implementation be carried out by educators whose professionalism can be relied on. Improving education quality is a development goal in the field of national education, and it is an essential component of efforts to improve the overall quality of the Indonesian people. The quality of education is influenced by several factors and one of them is management.

According to Stoner in Siswanto [5] management is the process of planning, coordinating, leading, and overseeing members of an organization, as well as the use of all other organizational resources, to accomplish the organization's goals. To realize good management in an organization requires a manager who has professional skills in his field, and that also applies in the world of education, especially schools, the quality of school management will depend on a principal who acts as a manager. As a manager, the headmaster has great duties and responsibilities in managing the school. The success of the headmaster in managing the school will not be separated from the ability of the headmaster as the school leader in carrying out the functions and roles of the headmaster. Therefore, a principal is required to be able to have readiness in managing the school, the readiness of the leadership referred to here is managerial ability related to Akadum [7] Principal/Madrasah Standards, the managerial ability of the principal includes: planning, organizing, deploying and supervision. With good managerial ability, it is expected that each principal can be a driver and enforcer of discipline for teachers so that they can show their performance productivity well.

Starting with the idea of Dikdasmen [8] performance is defined as the result of work that an employee achieves in terms of quality and quantity while carrying out his duties in accordance with the responsibilities assigned to him. A teacher's duties under the Indonesian National Education System, as stated in Article 39 paragraph 2, are to plan and carry out the learning process, determine learning outcomes, conduct mentoring and training, and conduct research and community service. This means that, in addition to the teaching or learning process, teachers must also carry out mentoring and trainings, as well as conduct research and provide service to the community.

The success of the headmaster in carrying out his duties was influenced by various factors, including the participation factor of the school community and support from various parties in Susanto [10], the participation of teachers and the community in improving the quality of education in the school setting would greatly assist the headmaster's duties. But in reality, the quality of teachers is still low so it is not necessarily able to carry out the duties assigned by the headmaster according to Al-Jawi [11]. In addition, community participation towards improving the quality of education in schools is also still lacking [10]. This is what makes the headmaster have to carry out his duties independently. Another factor that the headmaster needs in carrying out his duties is the support from the government, both in the form of coaching and material support, but in reality, more government support is focused on teachers than to the headmaster, even though the headmaster is the key to the success of the school. The lack of government support is what makes the headmaster's duties even more difficult.

In addition, community participation in improving the quality of education in schools is also still lacking [10]. This is what makes the headmaster have to carry out his duties independently. Another effort made by the government is to reorient education management, namely from a central-based quality improvement management system to school-based quality improvement management. The essence of School Based Quality Improvement management is the autonomy of school management and participatory decision making to achieve school quality goals. Through this system, school managers or managers are authorized to organize and improve the education process according to their own initiatives so as to reduce the dependence of the central government. The above understanding shows that the school has greater authority to manage its schools, because "the school is more aware of the strengths, weaknesses, opportunities, and threats to him so that he can optimize the utilization of available resources to advance his school [8]. It requires changes in attitudes and behaviors from all components of the school, including principals, teachers, and administrative personnel, as well as parents and the community, in looking at, understanding, and helping, as well as tracking and reviewing the school's implementation. Changes in attitudes and behaviors will be possible if existing school resources are utilized and managed optimally and effectively by the principal as the person responsible for the implementation of education in the school. The demands of principals who have strong leadership and management skills are in fact inseparable from practical issues of education and issues related to the 
decentralization of education, namely: These often arise issues, among others; limitations of the authority of the headmaster which implies the low effectiveness of achieving educational targets in schools. This issue also concerns the lack of authority given to the headmaster in developing education management in schools including limited wiggle room in utilizing educational resources allocated to schools [12]. In terms of independence and creativity, the management of education in schools depends heavily on the reliability of a principal, where the headmaster has more authority to make decisions related to school management policies than the education management system managed by the central government. While in terms of openness, accountability of school management, the headmaster as the manager in managing and managing the school should pay attention to the inputs of school management. Management inputs in question include; clear tasks, detailed and systematic plans, programs that support the implementation of school residents to act, and the existence of an effective and efficient quality control system to ensure that agreed goals can be achieved. Director General. Therefore, in its implementation the headmaster is expected to apply the principles of efficiency, effectiveness, productivity and innovation in the management of education. Recognizing the importance of improving school quality as evidenced by the indicators of input quality, process quality, human resource quality, facility quality, management quality, and cost, it is appropriate to support "the managerial ability of the principal to improve the quality of education in the school.

The spirit of leadership in leading is the main milestone of an educational institution, especially in SD Negeri Lempuing Jaya SubDistrict, to achieve maximum teacher performance results in need of participatory leaders who mean that in their leadership is done in a persuasive way, creating harmonious cooperation, fostering loyalty, and participation of subordinates. Thus, the headmaster should be able to perform functions and duties as well as play the appropriate role, namely as a leader as well as a manager. In addition, the school as an agent of change, the headmaster must understand and develop his skills in implementing the change, if the headmaster wants the school he leads to be more effective.

Leadership problems are often intriguing because the quality of leadership determines whether or not an organization succeeds or fails. Leadership is the ability to persuade, mobilize, and direct actions at a person or group of people in order to accomplish a specific goal in a given situation. Leadership is a pivotal position in the management aspects of organizational life. Because a leader's leadership serves as a motivator in the process of collaboration among individuals in his organization. The leadership of a leader will be able to distinguish the characteristics of an organization from other organizations. Dynamic and effective leadership is the most important potential and difficult to find, but that does not mean that a leader is not capable of being a dynamic and effective leader. By understanding the theory of leadership will be able to increase his understanding of himself, know the weaknesses and advantages of his potential, and will be able to better understand how he should treat his subordinates

From the observations in the field in several public elementary schools in The District Lempuing Jaya Ogan Komering Ilir Regency, it is known that there are some problems in the implementation of the duties of the principal of teachers with declining performance caused, because of the leadership and management of principals who have skills, traits and types that are not good and lack of quality in building an educational institution. this condition is caused by many recruitment of principals who are not based on competency skills but political factors, it is also in line with the performance of teachers in SD Negeri Lempuing Jaya subdistrict which is still very low in the implementation of its duties, which occurs teachers in the development of instruments of assessment of learning outcomes are still low and the number of teachers who in teaching only give assignments and take notes to students without giving information in advance and in doing their work also without being based on a sense of responsibility such as, there are still many teachers who often do not come without giving information and come untimely.

With poor teacher performance conditions, it also directly affects student achievement, dikarnakan who interact directly in the learning process with students is the teacher, so that it causes the creation of the perception of most people that only teachers are responsible for the success of student learning. This is reflected in the participation of teachers and the community in improving the quality of education in the school sphere, which would greatly assist the headmaster's duties, but in reality, the quality of teachers is still low, so it is not always able to carry out the tasks assigned by the headmaster. As a manager who causes the headmaster's managerial responsibilities, including planning, to be carried out inefficiently, the difficulties faced by the headmaster in making the planning are, Because of the lack of initiative culture among teachers and employees to offer their views, the headmaster has difficulty gathering opinions from teachers and employees to make decisions in a planning. The difficulties encountered are differences in viewpoint, behaviors, desire, and skills of the teachers, making it difficult for the headmaster to unite the vision and mission in order to achieve the school's goals. The difficulty encountered in oversight is the vast burden of administrative tasks that are the responsibility of the principal, resulting in the principal's lack of emphasis on the implementation of the school program. Due to schools' lack of community influence, the public perceives teachers as the primary key to educational success or failure. The lack of monitoring and evaluation conducted by the principal on the school program. 
Thus, the influence between the quality of the headmaster's leadership is closely related to the improvement of various aspects of school life, such as the predicate of the school whose quality is good and the quality is not good is closely related to the quality of leadership and management of the principal, as the person responsible for the management of education in the school.

\section{METHODS}

This research is quantitative research that is ex post facto. According to Sudjana and Ibrahim [13] ex post facto is research that points to the treatment or manipulation of free variables has occurred before, just look at the effect on bound variables. Judging from its purpose, this research is a comparative ca ceremonial research. Comparative causal research involves research activities that begin from identifying the influence of one variable on another variable, then looking for possible causal variables. This study consisted of three variables, namely two free variables and one bound variable. The free variables in this study are leadership $\left(\mathrm{X}_{1}\right)$ and principal management $\left(\mathrm{X}_{2}\right)$, while the variables tied to this research are teacher performance $(\mathrm{Y})$. The population in this study consisted of all teachers of SD Negeri in Lempuing Jaya Subdistrict of Ogan Komering Ilir Regency, a total of 259 people, with a sample of 72 people drawn using the Slovin formula.

Teacher achievement is the success rate of teachers in carrying out educational tasks in accordance with their duties and authorities based on performance standards set during a specific period in achieving goals. Teacher performance is measured by six indicators, namely the quality of the learning process, the effectiveness and efficiency of teaching and learning implementation, development and innovation of the teacher profession, research productivity and community service to work morale, job satisfaction.

Leadership is the ability to influence a group toward the establishment of a goal through interaction based on formal and non-formal roles. Leadership is measured by seven indicators, namely; the use of influence, transformation of vision and mission, distinction, mobilization, motivation, direction and guidance, the formation of commitments.

The headmaster's management is a series of processes in the form of a plan for the realization of a goal, organizing, mobilizing, controlling human resources effectively and efficiently and evaluating the series of process of development and improvement of the quality of education so that the objectives of education nationally, as well as the objectives of school education can be jointly realized. Principal management variables are measured using four indicators, specifically, planning, coordinating, processing, supervising, and evaluating.

\section{RESULTS AND DISCUSSION}

The Influence of Leadership on the Performance of State Elementary School Teachers in Lempuing Jaya Subdistrict Ogan Komering Ilir Regency

The findings of this study revealed that leadership has a major impact on the performance of state elementary school teachers in Lempuing Jaya Subdistrict, Ogan Komering Ilir Regency. This is evidenced by the signification value of the hypothetical test result obtained probability value $(0.000)$ less than the value of $\alpha(0.05)$, in addition, for the value tcount $(5,311)$ greater ttable $(1,996)$ so that it can be concluded that $\mathrm{Ha}$ is accepted. That is, there is an influence of leadership on the performance of state elementary school teachers in Lempuing Jaya Subdistrict, Ogan Komering Ilir Regency.

Leadership is defined as the ability to persuade or inspire a person or group of people to work voluntarily to accomplish specific goals or objectives in specific circumstances, so that leadership in addition to being required to be able to lead or manage the school, is also required to be able to create a conducive atmosphere in the work environment (climate-maker) so as to improve teacher performance.

The Influence of Principal Management on the Performance of Public Elementary School Teachers in Lempuing Jaya Subdistrict Ogan Komering Ilir Regency.

The findings of this study revealed that principal management has a major impact on the performance of elementary school teachers in Lempuing Jaya Subdistrict, Ogan Komering Ilir Regency. This is evidenced by the signification value of the hypothetical test result obtained probability value $(0.000)$ less than the value of $\alpha(0.05)$, in addition, for the value thitung $(4,954)$ greater ttabel $(1,996)$ so that it can be concluded that $\mathrm{Ha}$ is accepted. That is, principal management has an impact on the performance of state elementary school teachers in Lempuing Jaya subdistrict, Ogan Komering Ilir Regency.

Headmaster management uses management inputs by carrying out management functions, namely planning, organizing, coordinating, supervising and assessing human resources and other resources effectively and efficiently in achieving school goals. This management ability shows that the headmaster acts as a manager, there are three important things related to the management of the principal is the process, utilization of all organizational resources, and achievement of the objectives of the organization to be achieved.

The findings of this study are consistent with the findings of Faisal [15], which concluded that the principal's management had a significant impact on the performance of junior high school teachers in the 
Brebes district. Similarly, Dikdasmen [16] concluded that the headmaster's managerial ability influences the performance of public elementary school teachers in Yogyakarta's Kotagede Subdistrict.

The Influence of Leadership and Management of Principals Together on the Performance of State Elementary Teachers in Lempuing Jaya Subdistrict Ogan Komering Ilir Regency

The findings of this study revealed that principal leadership and management have a major impact on the performance of elementary school teachers in the Lempuing Jaya subdistrict, Ogan Komering Ilir Regency. This is evidenced by the signification value of the hypothetical test result obtained probability value (0.000) less than the value of $\alpha(0.05)$, in addition, for the value of Fhitung of 14,138 greater than Ftabel (0.05) of 3,130 so that Ha is accepted. This can be interpreted that there is a significant impact of principal leadership and management on the performance of elementary school teachers in Lempuing Jaya subdistrict, Ogan Komering Ilir Regency. The influence of leadership and management of principals together on teacher performance was $29.1 \%$ of the remaining $70.9 \%$ influenced by other factors that were not meant by variables in this study.

Teacher performance is essentially the result of interaction between various factors including leadership and management of the principal. By stating that performance is the end result of one's work and behavior. Performance, as a human act, is directed at the execution of organizational tasks that become the roles, authorities, and responsibilities of each member of the organizationTeacher performance refers to the quality and quantity of performance generated by teachers as a result of the influence of the headmaster's leadership and management in order to achieve the school's goals together. Indicators of teacher performance are teacher performance in terms of quality of learning process, effectiveness, and efficiency of learning process, teacher productivity in the field of education, research and community service, teacher spirit, and teacher satisfaction in order to achieve school goals so that the teaching and learning process in schools can be maximized and good educational quality can be realized.

Leadership is divided into several types: 1) autocratic leadership; 2) laissez faire leadership (stupid times); 3) democratic leadership; 4) charismatic leadership, and 5) militaristic leadership. In this case the leadership is influential with problem solving and related to the development of the group Thus subordinates will be passionate in working and carrying out their duties well. In addition, leaders must also be able to coordinate their organizations. With good coordination, the organization will also run well. Leadership can occur anywhere because it is a process of persuading others to do something in order to achieve a particular goal.

Headmaster management means the ability of the headmaster to use management inputs by carrying out management functions, namely planning, organizing, coordinating, supervising and assessing to manage human resources and other resources effectively and efficiently in achieving school goals. So that the objectives of education nationally, as well as the objectives of school education can be jointly realized. Therefore, with good leadership and management the headmaster is expected to improve teacher performance.

\section{CONCLUSION}

Based on the findings of the study and discussions, it is possible to conclude that: 1) leadership has an impact on the performance of elementary school teachers in Lempuing Jaya Subdistrict, Ogan Komering Ilir Regency; 2) there is an influence of principal management on the performance of elementary school teachers in Lempuing Jaya Subdistrict, Ogan Komering Ilir Regency; and 3) there is an influence of principal leadership and management combined on the performance of elementary school teachers in Lempuing Jaya Subdistrict, Ogan Komering Ilir Regency.

\section{ACKNOWLEDGMENT}

Our deepest gratitude goes to Teachers in SD Negeri in Lempuing Jaya Subdistrict, Ogan Komering Ilir, Chancellor of Palembang PGRI University, Director of the Postgraduate Program of PGRI Palembang University and the Education Management Study Program of PGRI Palembang University, who have supported us in doing this extraordinary thing. This project is funded independently. We also want to thank our Education Management friends who helped us a lot in a short time frame to complete this project.

\section{REFERENCES}

[1] Permendiknas RI. Number 16 Year 2007, About: Standards of Academic Qualifications and Teacher Competencies.

[2] Damin., Sudarwan., \& Suparno. (2009). Headmaster's Transformational Management and Leadership: Vision and Strategy for Successful Technology Era, Crisis Situation and International Education. Jakarta: PT. Rineka Cipta.

[3] Tjutju., Yuniarsih., \& Suwatno. (2011). Human Resource Management. Bandung: Alfabeta

[4] Risnawatiririn, (2009) Teacher Performance Concept. Yogyakarta: UPP STIM YKPN

[5] Siswanto, (2005). Manajemen Tenaga Kerja Indonesia Pendekatan Administratif dan Operasional [Indonesian Workforce Management 
Administrative and Operational Approaches]. Jakarta: Bumi Aksara.

[6] Permendiknas RI. Number 13 Year 2007, About: Standards of Principals / Madrasahs, Managerial Ability of principals include: Planning, Organizing, Deployment and Supervision.

[7] Akadum. (1999). Portraits of Teachers Entering the Third Millennium. The Sound of Renewal. (Online).

(http://www.suarare.com/News/1999/01/220199/O pEd), accessed June 7, 2020).

[8] Dikdasmen. (2000). Jss Performance Assessment Signs - High School. Jakarta: Dikdasmen Ministry of National Education ri.

[9] Law No. 20 of 2003, on the National Education System.

[10] Susanto. (2008). Implementation of MPMBS in Trucuk Elementary School, Panjangan Subdistrict, Bantul: Thesis. PPs-UNY.

[11] Al-Jawi, M. S. (2006). Education in Indonesia Problems and Solution. http://khilafah1924.org. Retrieved June 30, 2020.

[12] Brotosejati, B. (2002). Central Java Provincial Government Policy in the Field of Education Era of Regional Autonomy, Seminar Paper on Revitalization of Primary and Secondary Education. Magelang: Muhammadiyah University of Magelang.

[13] Sudjana, N.N., \& Ibrahim, (2010). Education Research and Assessment. Bandung: Sinar Baru Algensindo.

[14] Syaroni, (2006). The Influence of Leadership Performance and Management of Principals on The Performance of Public Junior High School Teachers in Brebes District. Postgraduate Program of Semarang State University. Vol. 1-101. Isbn. 1103505086.

[15] Faisal. (2012). The Influence of The Headmaster's Managerial Ability on the Performance of Teachers of Public Elementary Schools in Kotagede SubDistrict of Yogyakarta. Journal of Yogyakarta State University.

[16] Dikdasmen, (2002). Competence: Have a Leadership Spirit. Jakarta: Ditjend. Dikdasmen. 